\title{
Comparison of libido, Female Sexual Function Index, and Arizona scores in women who underwent laparoscopic or conventional abdominal hysterectomy
}

\author{
Laparoskopik veya konvansiyonel abdominal histerektomi \\ yapılan kadınlarda libido, Kadın Seksüel Fonksiyon İndeksi ve \\ Arizona skorlarının karşılaştırılması
}

\author{
Semra Kayataş, Enis Özkaya, Murat Api, Seyhan Çıkman, Ayşen Gürbüz, Ahmet Eser \\ Zeynep Kamil Women and Children's Health Training and Research Hospital, Clinic of Obstetrics and Gynecology, İstanbul, Turkey
}

\begin{abstract}
Objective: The aim of the present study was to compare female sexual function between women who underwent conventional abdominal or laparoscopic hysterectomy.

Materials and Methods: Seventy-seven women who were scheduled to undergo hysterectomy without oophorectomy for benign gynecologic conditions were included in the study. The women were assigned to laparoscopic or open abdominal hysterectomy according to the surgeons preference. Women with endometriosis and symptomatic prolapsus were excluded. Female sexual function scores were obtained before and six months after the operation from each participant by using validated questionnaires.

Results: Pre- and postoperative scores of three different quationnaires were found as comparable in the group that underwent laparoscopic hysterectomy $(\mathrm{p}>0.05)$. Scores were also found as comparable in the group that underwent laparotomic hysterectomy ( $>0.05)$. Pre- and postoperative values were compared between the two groups and revealed similar results with regard to all three scores $(\mathrm{p}>0.05)$.

Conclusion: Our data showed comparable pre- and the postoperative scores for the two different hysterectomy techniques. The two groups were also found to have similar pre- and postoperative score values.

Keywords: Sexual function, libido, hysterectomy, Female Sexual Function Index, Arizona Sexual Experiences Scale

$\ddot{\mathrm{O} z}$

Amaç: Bu çalışmanın amacı laparoskopik veya konvansiyonel abdominal histerektomi yapılan kadınlarda kadın seksüel fonksiyonlarının karşılaştırılmasıdır. Gereç ve Yöntemler: Ooforektomisiz histerektomi yapılması planlanan 77 kadın çalışmaya dahil edildi. Cerrahın tercihine göre hastalar laparoskopik veya konvansiyonel abdominal histerektomi yapılmak üzere iki gruba randomize edildi. Endometriozis ve/veya semptomatik pelvik organ prolapsusu olan hastalar dışlandı. Kadın seksüel fonksiyon skorları ameliyat öncesinde ve 6 ay sonrasında valide edilmiş anketlerle sorgulandı.

Bulgular: Laparoskopik histerektomi yapılan grupta ameliyat öncesinde ve sonrasında yapılan skorlama sonuçları benzerdi ( $>00,05)$. Skorlar laparotomik histerektomi yapılan grupta da benzer saptandı ( $>>0,05)$. İki grup arasında her üç anket için pre- and postoperatif skorlar benzerdi ( $>0,05)$.

Sonuç: Çalışmamızda her iki histerektomi tipinde pre- ve postoperatif skorlar benzer saptandı. Gruplar içinde pre- ve postoperatif skorlar benzerdi. Anahtar Kelimeler: Seksüel fonksiyon, libido, histerektomi, Kadın Seksüel Fonksiyon İndeksi, Arizona Seksüel Deneyimler Ölçeği
\end{abstract}

Address for Correspondence/Yazışma Adresi: Enis Özkaya, MD,

Zeynep Kamil Women and Children's Health Training and Research Hospital, Clinic of Obstetrics and Gynecology, İstanbul, Turkey

Phone: +902163910680 E-mail: enozkaya1979@gmail.com

Received/Geliș Tarihi: 01.11.2016 Accepted/Kabul Tarihi: 10.04.2017

${ }^{\circledR}$ Copyright 2017 by Turkish Society of Obstetrics and Gynecology

Turkish Journal of Obstetrics and Gynecology published by Galenos Publishing House. 
PRECIS: Comparable pre- and the postoperative sexual function scores were obtained following two different hysterectomy techniques.

\section{Introduction}

Hysterectomy is a commonly performed surgical procedure ${ }^{(1)}$. Hysterectomy can be performed via the vaginal route or by applying minimally invasive techniques (laparoscopy, robotic surgery). Approximately 50\% of cases undergo concomitant bilateral oophorectomy ${ }^{(2)}$, as a consequence, estrogen deficiency may influence women's health. Furthermore, estrogen and androgen deficiency secondary to oophorectomy may aggrevate climacteric symptoms and sexual dysfunction, which may affect sexual pleasure, comfort, and frequency, resulting in lower desire, arousal, lubrication and sexual satisfaction. In addition, coital pain is a frequent sexual problem reported after perimenopausal oophorectomy ${ }^{(3)}$.

Some validated and non-validated quastionnaires introduced the term "sexual function" as an overall descriptive term for outcomes $^{(4)}$ that include sexual activity and sexual function in terms of specific functional aspects, as well as satisfaction with sexual activity.

Age, menopausal status, systemic diseases, and also gynaecologic surgery were reported to adversely affect the sexual response ${ }^{(5)}$. It was reported that gynaecologic surgery may interfere with sexuality in middle-age women and some factors played a significant role leading to dysfunction, including changing selfimage, sexual pain and orgasm difficulty ${ }^{(6)}$. Sexual wellbeing may differ according to the type of hysterectomy because different techniques damage the innervation and supportive structures of the pelvic floor. Recent technical advances made laparoscopic surgery possible in many surgical fields and laparoscopy became a feasable technique for hysterectomy ${ }^{(7)}$.

In this study, we aimed to assess the effect of laparotomic versus laparoscopic hysterectomy techniques on the Female Sexual Function Index (FSFI), the Libido Scoring System (LSS), and Arizona scores.

\section{Materials and Methods}

\section{Participants}

This prospective observational study was performed at the Gynecology Clinic of Zeynep Kamil Women and Children's Health Training and Reseach Hospital between June 2014 and December 2015. Informed consent was obtained from each participant.

Seventy-seven consecutive women who were sexually active and healthy premenopausal patients, aged between 40-55 years, and were offered hysterectomy for benign indications either via laparotomy or laparoscopy were included in the study. The technique of hysterectomy was determined according to the surgeon's preference. Exclusion criteria consisted of endometriosis, symptomatic prolapsus, chronic pelvic pain and malignancy as indications for surgery, patients with sexual dysfunction, participation refusal or reduced capability of understanding the survey, patients with severe depression or had been using antidepressant treatment, and patients whose partner had a severe illness or had died recently. Patients who required oophorectomy during the operation $(n=3)$, developed complications in the postoperative period $(n=2)$, and those who refused to participate in the study after the operation $(n=6)$ were excluded.

The FSFI, Arizona, and LSS questionnaires were completed in face-to-face sessions. Sociodemographic data (personal and partner) were recorded. In total, 66 patients completed these questionnaires for evaluating sexual function prior to and six months after hysterectomy. Hysterectomies were performed by the same surgical team according to standard surgical techniques.

\section{The Female Sexual Function Index}

The FSFI is a validated self-administered questionnaire that consists of 19 questions and measures six domains of sexual function: desire, arousal, lubrication, orgasm, satisfaction and pain $^{(8)}$. The first and second questions have scales from 1 to 5 and other questions have scales from 0 to 5 for scoring. Scores obtained in a particular domain are added and multiplied by a respective factor (coefficients for questions 1-2: 0.6; 3-10: 0.3; 11-19: 0.4), which homogenizes the influence of each dimension. A total sum of each score is obtained and higher scores indicate healthy sexual life. Score ranges between 1.2 and 36. An optimal cut-off was introduced as $26^{(9)}$. In the present study, an FSFI score of 26 or less was defined as sexual dysfunction. Validation of this questionnaire in Turkish population was shown in previous reports ${ }^{(10)}$.

\section{The Arizona Sexual Experiences Scale}

The Arizona Sexual Experiences Scale (ASEX) has five items that assess sexual experiences including: drive, arousal, vaginal lubrication, ability to reach orgasm, and satisfaction with orgasm. The lubrication item is assessed by the versions specific for sex. Each item is rated with a six-point scale. Scores range between 5 and 30; higher scores indicate better sexual life. Use of this questionnaire was shown in previous reports ${ }^{(11)}$.

\section{The Libido Scoring System}

LSS was developed in 1997 by Api et al. ${ }^{(12)}$. It comprises four questions on four domains: orgasmic function, coital frequency, sexual desire, and sexual self-interest (masturbation). FSFI was well-correlated with the LSS, revealing a correlation coefficient of 0.96 ( $p<0.001$ ) (the Cronbach's $\alpha$ coefficient was found as 0.83 and the total kappa values were 0.67 and 0.77$)^{(12)}$. The patients were scored and a total score less than 3 was considered as loss of libido; scores of 3 and 4 were considered as low libido, 
5-7 as moderate libido, and 8-12 as high libido. The researcher asked the following questions to the patients:

1. How often do you have sex or masturbate?

2. Do you masturbate?

3. Who starts the sexual activity? (Who asks for or implies sex first?)

4. Do you have orgasm during masturbation or sexual intercourse?

\section{Statistical Analysis}

Data were analyzed using SPSS 15.0 for Windows. Student's t-test was used to compare continuous variables between the groups. The paired samples t-test was used to show comparisons of continuous variables before and after intervention. $\mathrm{P}$ values $<0.05$ were accepted as statistically significant.

\section{Results}

The groups were similar with regard to their mean age (44 vs. 46 years) and mean uterine volume (730 vs. $1050 \mathrm{~cm}^{3}$, $\mathrm{p}>0.05)$. The pre- and postoperative scores of the three different quationnaires were found as comparable in the group that underwent laparoscopic hysterectomy ( $p>0.05$, Table 1). Scores were also found as comparable in the group that underwent laparotomic hysterectomy ( $>0.05$, Table 2). Pre- and postoperative values were compared between the two groups, which revealed similar results with regards to all three scores ( $p>0.05$, Table 3).

\section{Discussion}

In this study, we compared the pre- and the postoperative sexual function of women who underwent laparoscopic or laparotomic hysterectomy. Our data revealed comparable preand postoperative scores between the groups. The comparison of pre- and postoperative score values within each group revealed similar results. We preferred to assess sexual function at the $6^{\text {th }}$ postoperative month based on a study that indicated a requirement of 6 months for pelvic innervation recovery ${ }^{(13)}$.

Hysterectomy is a frequently performed gynecologic surgery for variable indications. Sexual function after hysterectomy with

Table 1. Comparison of pre- and postoperative scores of three different sexual function evaluation questionnaires in women who underwent laparoscopic hysterectomy

\begin{tabular}{|lllll|} 
& Mean & $\mathrm{n}$ & $\begin{array}{l}\text { Standard } \\
\text { deviation }\end{array}$ & $\mathrm{p}$ \\
\hline Preoperative libido & 3.6 & 35 & 1.5 & $>0.05$ \\
\hline Postoperative libido & 3.6 & 35 & 1.5 & \\
\hline Preoperative FSFI & 21.6 & 35 & 7.8 & $>0.05$ \\
\hline Postoperative FSFI & 23.6 & 35 & 6.4 & \\
\hline Preoperative Arizona & 16.3 & 35 & 5.2 & $>0.05$ \\
\hline Postoperative Arizona & 15.9 & 35 & 4.5 & \\
\hline
\end{tabular}

FSFI: Female Sexual Function Index different techniques has been questioned in several trials and generally it was thought that injury to the uterovaginal plexus during hysterectomy might interfere with the neuronal support of vagina, which leads to affected orgasm and lubrication ${ }^{(14,15)}$. There are also some data indicating similar sexual function in women with and without cervical ablation ${ }^{(16,17)}$, and studies also showed similar sexual function among different hysterectomy techniques including total abdominal hysterectomy, subtotal hysterectomy, and vaginal hysterectomy ${ }^{(18)}$.

A recently published review on this issue assessed the results of previously published studies and summarized the results under different headings including sexual desire, sexual arousal,

Table 2. Comparison of pre- and postoperative scores of three different sexual function evaluation questionnaires in women who underwent laparotomic hysterectomy

\begin{tabular}{|lllll|} 
& Mean & $\mathrm{n}$ & $\begin{array}{l}\text { Standard } \\
\text { deviation }\end{array}$ & $\mathrm{p}$ \\
\hline Preoperative libido & 3.6 & 31 & 1.7 & \\
\hline Postoperative libido & 3.9 & 31 & 1.6 & $>0.05$ \\
\hline Preoperative FSFI & 21.7 & 31 & 7.8 & \\
\hline Postoperative FSFI & 23.2 & 31 & 5.6 & $>0.05$ \\
\hline Preoperative Arizona & 17.4 & 31 & 6.9 & \\
\hline Postoperative Arizona & 15.2 & 31 & 4.4 & $>0.05$ \\
\hline
\end{tabular}

FSFI: Female Sexual Function Index

Table 3. Comparison of three different sexual function evaluation questionnaire scores between women underwent laparoscopic and laparotomic hysterectomy

\begin{tabular}{|c|c|c|c|c|c|}
\hline & Groups & $\mathrm{n}$ & Mean & $\begin{array}{l}\text { Standard } \\
\text { deviation }\end{array}$ & $\mathrm{p}$ \\
\hline \multirow{2}{*}{$\begin{array}{l}\text { Preoperative } \\
\text { libido }\end{array}$} & LS & 35 & 3.6 & 1.5 & \\
\hline & LPT & 31 & 3.6 & 1.7 & $>0.05$ \\
\hline \multirow{2}{*}{$\begin{array}{l}\text { Postoperative } \\
\text { libido }\end{array}$} & LS & 35 & 3.6 & 1.4 & \\
\hline & LPT & 31 & 3.9 & 1.6 & $>0.05$ \\
\hline \multirow{2}{*}{$\begin{array}{l}\text { Preoperative } \\
\text { FSFI }\end{array}$} & LS & 35 & 21.6 & 7.7 & \\
\hline & LPT & 31 & 21.7 & 7.1 & $>0.05$ \\
\hline \multirow{2}{*}{$\begin{array}{l}\text { Postoperative } \\
\text { FSFI }\end{array}$} & LS & 35 & 23.6 & 6.4 & \\
\hline & LPT & 31 & 23.2 & 5.6 & $>0.05$ \\
\hline \multirow{2}{*}{$\begin{array}{l}\text { Preoperative } \\
\text { Arizona }\end{array}$} & LS & 35 & 16.2 & 5.1 & \\
\hline & LPT & 31 & 17.4 & 6.9 & $>0.05$ \\
\hline \multirow{2}{*}{$\begin{array}{l}\text { Postoperative } \\
\text { Arizona }\end{array}$} & LS & 35 & 15.8 & 4.4 & \\
\hline & LPT & 31 & 15.2 & 4.4 & $>0.05$ \\
\hline \multirow{2}{*}{ Uterine volume } & LS & 35 & 730.9 & 1321.6 & \\
\hline & LPT & 31 & 1050.2 & 1007.3 & $>0.05$ \\
\hline
\end{tabular}


orgasm, dyspareunia and sexual satisfaction, and the authors reported contradictory results with regard to these sexual parameters ${ }^{(19)}$. All these parameters were assessed by using three different questionnaires in our study. We found similar pre- and postoperative scores for each technique.

In contrast to our results, some studies in the literature showed measurable advances in life style and sexual function after simple hysterectomy, whereas others revealed negative results ${ }^{(20-23)}$. Furthermore, a previous study indicated that hysterectomy contributed to quality of life with minimal postoperative morbidity after minimally invasive surgery ${ }^{(24)}$.

Consistent with our results, according to some prospective, randomized studies, late psychosexual changes have not been thought to primarily depend on the surgical method (vaginal, abdominal total or subtotal hysterectomy); studies showed the quality of sexual relationship before the operation as the most significant predictive factor ${ }^{(25)}$.

The aforementioned conclusions show several conflicting results with regard to the impact of hysterectomy on sexual function. Some authors suggested that the parameters of questionnaires were unsatisfactory for assessing sexual function ${ }^{(26)}$.

Meta-analyses on this issue revealed that prolapsus operations, particularly posterior repairs using levator plication, seemed to deteriorate sexual function, and hysterectomy was found to improve sexual function, regardless of whether it was subtotal or total. The review concluded that gynecologic operations might influence sexual function; however, little validated data are available to come to this conclusion ${ }^{(27)}$. Due to the lack of validated data, we performed this study by using three different scoring systems including ASEX, which was shown to be a valid and reliable instrument for use in clinical trials on sexual function in the Turkish population ${ }^{(28)}$, and FSFI scoring, which has been used in several different studies in the Turkish population; validation of this scoring system for the Turkish population has been shown ${ }^{(29,30)}$. Finally, we also tried to confirm our results by the third different scoring system introduced by the Api et al. ${ }^{(12)}$ who concluded that this simple test provided a reliable measure for routine clinical practice or trial purposes.

Most of the studies in the literature included heterogeneous groups of participants to assess sexual function and the majority failed to exclude patients with certain factors (e.g., menopausal status, comorbidity, oophorectomy, endometriosis, malignity), which may interfere with the results ${ }^{(31)}$. Our data originated from a homogeneous group of patients from a single tertiary referral center; most women with the aforementioned factors that may be interfere with the results were excluded from our study and we used three different questionnaires comprising different parameters to assess the effect of surgical technique on sexual function.

\section{Study Limitations}

Small sample size is the major drawback in our study.

\section{Conclusion}

Our data showed comparable pre- and the postoperative scores for the two different hysterectomy techniques. Pre- and postoperative scores were similar within each surgical technique, using three different questionnaires revealed no effect of surgical technique on sexual function after hysterectomy.

\section{Ethics}

Ethics Committee Approval: Ethics committee approval was not obtained because of the observational study.

Informed Consent: Consent form was filled out by all participants.

Peer-review: Externally peer-reviewed.

\section{Authorship Contributions}

Surgical and Medical Practices: M.A., A.E., S.Ç., Concept: S.Ç., Design: S.Ç., A.G., Data Collection or Processing: S.Ç., Analysis or Interpretation: E.Ö., Literature Search: E.Ö., Writing: E.Ö., S.K.

Conflict of Interest: No conflict of interest was declared by the authors.

Financial Disclosure: The authors declared that this study received no financial support.

\section{References}

1. Whiteman MK, Hillis SD, Jamieson DJ, Morrow B, Podgornik MN, Brett KM, et al. Inpatient hysterectomy surveillance in the United States, 2000-2004. Am J Obstet Gynecol 2008;198:34.e1-7.

2. Parker WH. Bilateral oophorectomy versus ovarian conservation: effects on long-term women's health. J Minim Invasive Gynecol 2010;17:161-6.

3. Hickey M, Ambekar M, Hammond I. Should the ovaries be removed or retained at the time of hysterectomy for benign disease? Hum Reprod Update 2010;16:131-41.

4. Lonnée-Hoffmann R, Pinas I. Effects of Hysterectomy on Sexual Function. Curr Sex Health Rep 2014;6:244-251.

5. Veronelli A, Mauri C, Zecchini B, Peca MG, Turri O, Valitutti MT, et al. Sexual dysfunction is frequent in premenopausal women with diabetes, obesity, and hypothyroidism, and correlates with markers of increased cardiovascular risk. A preliminary report. J Sex Med 2009;6:1561-8.

6. Nappi RE, Albani F, Chiovato L, Polatti F. Local estrogens for quality of life and sexuality in postmenopausal women with cardiovascular disease. Climacteric 2009;12(Suppl 1):112-6.

7. Munro MG, Deprest J. Laparoscopic hysterectomy: does it work?: a bicontinental review of the literature and clinical commentary. Clin Obstet Gynecol 1995;38:401-25.

8. Rosen R, Brown C, Heiman J, Leiblum S, Meston C, Shabsigh R, et al. The Female Sexual Function Index (FSFI): a multidimensional selfreport instrument for the assessment of female sexual function. J Sex Marital Ther 2000;26:191-208.

9. Wiegel M, Meston C, Rosen R. The female sexual function index (FSFI): cross-validation and development of clinical cutoff scores. J Sex Marital Ther 2005;31:1-20.

10. Verit FF, Verit A. Validation of the female sexual function index in women with chronic pelvic pain. J Sex Med 2007;4:1635-41.

11. Önem R, Çelik S, Öncü J, Tankaya O, Kolat U, Sungu Danışmant B, et al. Assessment of Marital Adjustment and Sexuality in Women With Rheumatoid Arthritis. Arch Rheumatol 2014;29:280-8. 
12. Api M, Api O, Görgen H, Çetin A, Yayla M. New diagnostic instrument for sexual function assessment in menopausal women: Libido scoring system. J Turk Ger Gynecol Assoc 2005;6:24-9.

13. Sultan AH, Kamm MA, Hudson CN. Pudendal nerve damage during labour: prospective study before and after childbirth. Br J Obstet Gynaecol 1994;101:22-8.

14. Fram KM, Saleh SS, Sumrein IA. Sexuality after hysterectomy at University of Jordan Hospital: a teaching hospital experience. Arch Gynecol Obstet 2013;287:703-8.

15. Richter DL, McKeown RE, Corwin SJ, Rheaume C, Fraser J. The role of male partners in women's decision making regarding hysterectomy. J Womens Health Gend Based Med 2009;9(Suppl 2):S51-61.

16. Zobbe V, Gimbel H, Andersen BM, Filtenborg T, Jakobsen K, Sørensen HC, et al. Sexuality after total vs. subtotal hysterectomy. Acta Obstet Gynecol Scand 2004;83:191-6.

17. Lethaby A, Mukhopadhyay A, Naik R. Total versus subtotal hysterectomy for benign gynaecological conditions. Cochrane Database Syst Rev 2012;18:4:CD004993.

18. Roovers JP, van der Bom JG, van der Vaart $\mathrm{CH}$, Heintz AP. Hysterectomy and sexual wellbeing: prospective observational study of vaginal hysterectomy, subtotal abdominal hysterectomy, and total abdominal hysterectomy. BMJ 2003;327:774-8.

19. Danesh M, Hamzehgardeshi Z, Moosazadeh M, Shabani-Asrami F. The Effect of Hysterectomy on Women's Sexual Function: a Narrative Review. Med Arch 2015;69:387-92.

20. Mokate T, Wright C, Mander T. Hysterectomy and sexual function. J Br Menopause Soc 2006;12:157-9.

21. Flory N, Bissonnette F, Amsel RT, Binik YM. The psychosocial outcomes of total and subtotal hysterectomy: A randomized controlled trial. J Sex Med 2006;3:483-91.
22. Punushapai U, Khampitak K. Sexuality after total abdominal hysterectomy in Srinagarind Hospital. J Med Assoc Thai 2006;89(Suppl 4):112-7.

23. Saini J, Kuczynski E, Gretz HF 3rd, Sills ES. Supracervical hysterectomy versus total abdominal hysterectomy: perceived effects on sexual function. BMC Womens Health 2002;2:1.

24. Siedhoff MT, Carey ET, Findley AD, Hobbs KA, Moulder JK, Steege JF. Post-hysterectomy dyspareunia. J Minim Invasive Gynecol 2014;21:567-75

25. Szeverényi P, Török Z. [The relationship between hysterectomy and sexual life according to the latest research]. Orv Hetil 2008;149:58995.

26. Mokate T, Wright C, Mander T. Hysterectomy and sexual function. J Br Menopause Soc 2006;12:153-7.

27. Ghielmetti T, Kuhn P, Dreher EF, Kuhn A. Gynaecological operations: do they improve sexual life? Eur J Obstet Gynecol Reprod Biol 2006;129:104-10

28. Soykan A. The reliability and validity of Arizona sexual experiences scale in Turkish ESRD patients undergoing hemodialysis. Int J Impot Res 2004;16:531-4.

29. Simsek A, Ozgor F, Yuksel B, Kucuktopcu O, Kirecci SL, Toptas M, et al. Female sexual function after transobturator tape in women with urodynamic stress urinary incontinence. Springerplus 2014;3:570.

30. Akkuzu G, Ayhan A. Sexual functions of Turkish women with gynecologic cancer during the chemotherapy process. Asian Pac J Cancer Prev 2013;14:3561-4.

31. Roovers JP, van der Bom JG, van der Vaart $\mathrm{CH}$, Heintz AP. Hysterectomy and sexual wellbeing: prospective observational study of vaginal hysterectomy, subtotal abdominal hysterectomy, and total abdominal hysterectomy. BMJ 2003;327:774-8. 